\title{
Genetic Control on the Performance of Common Bean Differential Cultivars to Colletotrichum lindemuthianum Races
}

\author{
Maria Celeste Gonçalves-Vidigal*, Lucimar Pereira Bonett, Pedro Soares Vidigal Filho, \\ Adriana Gonela and Aliny Simony Ribeiro \\ Departamento de Agronomia; Universidade Estadual de Maringá; Av. Colombo 5790; 87020-900; \\ mvidigal@pop.com.br; Maringá - PR - Brasil
}

\begin{abstract}
The aim of this work was to perform genetic control on differential cultivars Michelite, Michigan Dark Red Kidney, Perry Marrow, Cornell 49-242, PI 207262, AB 136 and G 2333 and its diallel hybrids by using Hayman's methodology. The entire $F_{1 s}$ populations were evaluated in relation to race 89 , whereas the race 31 , the diallel scheme did not include the cultivar $G$ 2333. The results showed that the additive effects were predominant for the 31 race, while non-additive effects were more important for race 89. The results demonstrated a high coefficient of genetic determination for the race 31. The G 2333, AB 136 and PI 207262 cultivars should be recommended obtaining cultivar resistant to anthracnose by backcross programs because theyshowed the highest proportion of resistant dominant alleles for the races 31 and 89.
\end{abstract}

Key words: Diallel analysis, genetic inferences

\section{INTRODUCTION}

The common bean (Phaseolus vulgaris L.) is one of the most important components of the Brazilian diet as it is a proven source of protein and is also a good source of carbohydrates and iron. Brazil is the largest world producer of common bean species (Vieira et al. 1998) and Paraná state contributes with $25 \%$ of the national production.

The common bean presents serious phytosanitary problems which result in the low national yield, generally below $600 \mathrm{~kg} \mathrm{ha}^{-1}$. Diseases are the most important reason for low bean yield in Brazil (Pompeu et al. 1992), among them, anthracnose, caused by Colletotrichum lindemuthianum (Saac. et Magn.) Scrib., is one of the most widespread and economically important fungal diseases of common bean. Genetic resistance is the most effective method of controlling anthracnose in common bean and their genetic characterization is essential to ensure novelty from previously characterized sources (Balardin et al., 1997; Melloto and Kelly, 2000; Pastor-Corrales et al., 1995; Poletine et al., 2000). Many races of the pathogen have been characterized in different parts of the world where dry beans are grown (Balardin et al., 1997; Garrido-Ramirez and Romero-Cova, 1989; Menezes and Dianese, 1988; Rava et al. 1994; Yerkes Júnior and Ortiz, 1956). In studies using the binary nomenclature for $C$. lindemuthianum race characterization (PastorCorrales, 1991) 25 physiological races of the pathogen in isolates from several regions of Brazil were identified (Rava et al. 1994), and fourteen

\footnotetext{
${ }^{*}$ Author for correspondence
} 
isolates from Paraná State were identified as belonging to the races $55,64,65,81,89,95,102$, and 453. Also, in Paraná state, Thomazella et al. (2000) identified nine races of $C$. lindemuthianum, being race 89 one the most frequent.

Among the biometrics methods for genetic analysis, the diallel cross has a special importance for genetic breeding. In this context, analysis of diallel crosses has been emphasized in many breeding programs for different crops because of the large amount of information they offer to the breeder (Cruz et al., 2004; Barelli et al., 2000). Hayman's procedure (1954), among the methodologies of diallel analysis available, is not based on previously established statistical models, but rather on knowledge of the environmental and genetic nature of statistics, such as means, variance, covariance, obtained from the diallel table (Cruz et al., 2004; Silva et al., 2004).

The present study was carried out to investigate the control of genetic resistance of the common bean to the races 31 and 89 of Colletotrichum lindemuthianum, using diallel analysis methodology described by Hayman (1954).

\section{MATERIALS AND METHODS}

The common bean cultivars Michelite, Michigan Dark Red Kidney, Perry Marrow, Cornell 49242, PI 207262, AB 136 and G 2333 were crossed in a diallel system without reciprocals. The entire $F_{1}$ population was evaluated in relation to the race 89 , whereas for the race 31 the diallel scheme did not include the cultivar G 2333. The races 31 and 89 were provided by Laboratories at the Nucleus of Research Applied to Agriculture (Nupagri) of the Agronomy Department at Maringá State University. These races were collected in the regions of the Paraná state.

\section{Preparation of inoculum, inoculation and incubation}

Cultures from of each race was incubated in Petri dishes containing either Mathur's (Mathur et al., 1950), PDA (potato-dextrose agar) or bean pod agar (Cárdenas et al., 1964) culture medium. These cultures were incubated at $25^{\circ} \mathrm{C}$ for 14 days and individual isolates were inoculated on the anthracnose differential series to confirm their phenotypes. Inoculations of the parents, $F_{1}$ of each cross were carried out separately to prevent contamination, with four replications. The protocol for inoculation was as follows: 14-day-old bean plants with fully developed first trifoliate leaves were spray-inoculated with a spore suspension (1.2 x $10^{6}$ spores per $\mathrm{mL}$ ) of each race of $C$. lindemuthianum. After the inoculation, the plants were maintained in a mist chamber for $48 \mathrm{~h}$ at $20^{\circ} \mathrm{C} \pm 2{ }^{\circ} \mathrm{C}$, under controlled light $(12 \mathrm{~h}$ with 680 lux illumination alternated with $12 \mathrm{~h}$ of darkness) and approximately $100 \%$ relative humidity.

\section{Symptoms evaluation}

The system proposed by Yerkes Jr. and Ortiz (1956) was used after approximately 10 days of the inoculation. The scores were assigned to the first trifoliate leaves, whose values were on a 1-to5 scale in individual plants to assess the symptoms induced by the physiological race. Plants were scored from 1 to 5 for the damage intensity caused by the physiological races. According to the Yerkes Jr. and Ortiz (1956) scale: score $1=$ no symptoms; score $2=$ symptoms on the secondary veins; score $3=$ symptoms in the main vein; score $4=$ symptoms in the petiole and score $5=$ total necrosis. This system was used in studies carried out by Cárdenas et al. (1964), Muhalet et al. (1981), Fukuda (1982), Del Peloso et al. (1989) and Gonçalves-Vidigal (1994).

\section{Treatments and experimental design}

The populations consisting of seven parents and 21 $F_{1}$, totaling 28 treatments were assessed in the greenhouse at the Nucleus for Research Applied to Agriculture (Nupagri), at the Department of Agronomy, UEM, Maringá, PR in 1997. The experiments were carried out as a randomized complete block design with four replications. The experimental unit consisted on a flat with 10 seedlings from of each parent and 10 seedlings from each $F_{1}$.

\section{Statistical analysis}

An analysis of variance using a randomized complete block design for the data of each characteristic was carried out. The value of each observation provided by the following statistical model, taking cultivar as fixed effects was used:

$\mathrm{Y}_{\mathrm{ij}}=\mathrm{m}+\mathrm{g}_{\mathrm{i}}+\mathrm{b}_{\mathrm{j}}+\mathrm{E}_{\mathrm{ij}}$,

where,

$\mathrm{Y}_{\mathrm{ij}}=$ observation of $\mathrm{i}^{\text {th }}$ treatment in the $\mathrm{j}^{\text {th }}$ block ( $\mathrm{i}$ $=1,2, \ldots, g=6 ; j=1,2, \ldots, b=10$ );

$\mathrm{m}=$ general mean; $\mathrm{g}_{\mathrm{i}}=$ effect of the $\mathrm{i}^{\text {th }}$ cultivar;

$b_{j}=$ effect of the $j^{\text {th }}$ block; $E_{i j}=$ experimental error. 


\section{Hayman's methodology (1954)}

The parents were considered different in a $\mathbf{T} / \mathbf{t}$ locus, with an $\mathbf{u}_{\mathbf{t}}$ proportion of favorable alleles and another $\mathbf{v}_{\mathbf{t}}$ of unfavorable alleles (Cruz et al., 2004), disabling the appliance of Hayman's methodology (1954). The computer Genes program (Cruz, 2001) was used for this.

The components of variance were obtained from the diallel table and by association among them and the genetic resistance parameters of the cultivars and their hybrids to the 31 , and 89 races of the pathogen were estimated. This model was adopted because the diallel analysis of the parents presented anthracnose symptoms classified from 1 to 5 .

\section{RESULTS AND DISCUSSION}

Sufficiency test of the additive-dominant model

Assuming that the genetic effects are the results of the additive and dominant action of genes, Hayman (1954) imposed a series of restrictions which required the application of tests to verify the sufficiency of the model. Table 1 shows the results of the applications of two tests for the 31, and 89 races assessed. The absence of significance in both tests confirmed that the imposed assumptions were valid and indicated that the additive-dominant model was adequate for the genetic study of these traits.

Table 1 - Sufficiency tests of the additive-dominant model, using Hayman's methodology (1954) for two races of Colletotrichum lindemuthianum among seven common bean parents

\begin{tabular}{ccc}
\hline \multirow{2}{*}{ Races } & Regression $^{\prime \mathbf{1}}$ & Rotation of the $\hat{W}_{i}$ and $\hat{V}_{i}^{2 /}$ \\
\cline { 2 - 3 } & $\mathbf{t}\left(\mathbf{H}_{\mathbf{0}}: \mathbf{b}=\mathbf{1}\right)$ & $\mathbf{F}=\mathbf{t}^{\mathbf{2}}\left(\mathbf{H}_{\mathbf{0}}: \mathbf{B}=\mathbf{b} \mathbf{- 1}=\mathbf{0}\right)$ \\
\hline 31 & $-1.003863 \mathrm{~ns}$ & $0.865678 \mathrm{~ns}$ \\
89 & $0.938531 \mathrm{~ns}$ & $-1.092034 \mathrm{~ns}$ \\
\hline
\end{tabular}

1/ $\mathrm{t}$ test, weighing the $\hat{\mathrm{W}}_{\mathrm{i}}+\hat{\mathrm{V}}_{\mathrm{i}}$, values, at the $5 \%$ levels of probability.

2/ $\mathrm{F}$ test, weighing the $\hat{\mathrm{W}}_{\mathrm{i}}$ and $\hat{\mathrm{V}}_{\mathrm{i}}$, axles by their $45^{\circ}$ rotation, at the $1 \%$ and $5 \%$ levels of probability; Ns = non significant at levels of 1 and $5 \%$ probability.

\section{Race 89}

There was positive correlation of $\mathrm{Y}_{\mathrm{r}}$ and $\left(\mathrm{W}_{\mathrm{r}}+\mathrm{V}_{\mathrm{r}}\right)$ of 0.9947 by the linear regression equation, showing that the appearance of the disease was negatively influenced by dominance. The dominant alleles demonstrated a decreasing of the disease incidence. According to Hayman (1954), the parent carrier of the greatest proportion of dominant genes shows the lowest value of $\hat{W}_{r}+$ $\hat{V}_{r}$ while the greatest proportion of recessive genes corresponds to the parent with greatest value of $\hat{W}_{r}+\hat{V}_{r}$.

Fig. 1 shows that the resistant parents (7) G 2333, (6) AB 136, (5) PI 207262, (3) Perry Marrow and (2) Dark Red Kidney were close to the lower extremity of the regression line, demonstrating that they contain a high proportion of dominant genes conferring resistance to the race 89 . The susceptible parents (1) Michelite and (4) Cornell 49242 were placed at the upper extremity, because they contain a high proportion of recessive genes.
This event demonstrated that the quantitative analysis through the use of Hayman's methodology was efficient to distinguish susceptible cultivar from the dominant ones. The predominance of dominant homozygous forms was detected by the analysis of the ratio between dominant and recessive genes in the parents of the group studied $\left(K_{D} / K_{R}=2.9333\right.$ ).

According to Table 2, the estimate $\tilde{D}-\tilde{H}$ with value greater than zero and the linear regression intercepting the $\mathrm{Wr}$ axle at a point above the origin (Fig. 1), indicated that the variance of the additive genetic effects was the most important for resistance to race 89 . The expression $\sqrt{\tilde{H} / \tilde{D}}$ indicates the occurrence of complete dominance. Therefore, in backcrossing programs for introgression of resistance to the race 89 , an enough large population should be used to carry out a greater number of tests to obtain desirable individuals to continue the program. 
Based on this assumption, the $\tilde{h}^{2} / \tilde{H}_{2}$ estimate (Table 3) allowed admission of the presence of at least one gene or genetic block, showing dominance for resistance to the race 89 . The value $\mathrm{F}=2.91$ (Table 2) was the indication of a greater frequency of dominant alleles than recessive alleles in the parents studied. This was confirmed by the graphic method (Fig. 1) where most of the parents were close to the lower extremity of the line, except the parents (1) Michelite and (4) Cornell 49-242. This fact could be explained because both were compatible with races 31 and 89 , respectively. As the dominant genes were favorable and recessive genes unfavorable for resistance to race 89 , this was translated into an allelic asymmetry represented by a value of $\tilde{H}^{2} / 4 \tilde{H}_{1}=0.1876$.

\section{Race 31}

The positive correlation $(\mathrm{r}=0.9967)$ between $Y_{r}$ and $\left(W_{r}+V_{r}\right)$ indicated that alleles that act in the sense of increasing the outbreak of the disease are predominantly recessive. In other words, resistance is conditioned to a greater concentration of dominant alleles in the individuals. The sum of the values $\hat{W}_{r}+\hat{V}_{r}$ indicated the relative concentration of dominant and recessive alleles. In this case, the dominance order was firstly in $\mathrm{AB}$ 136 and secondly in PI 207262. Similar results were obtained in studies carried out by Gonçalves-Vidigal (1994), Alzate-Marín (1996), Young and Kelly (1997), Poletine et al. (2000), who suggested that the $\mathrm{AB} 136$ parent has alleles resistant to several races of $C$. lindemuthianum races.

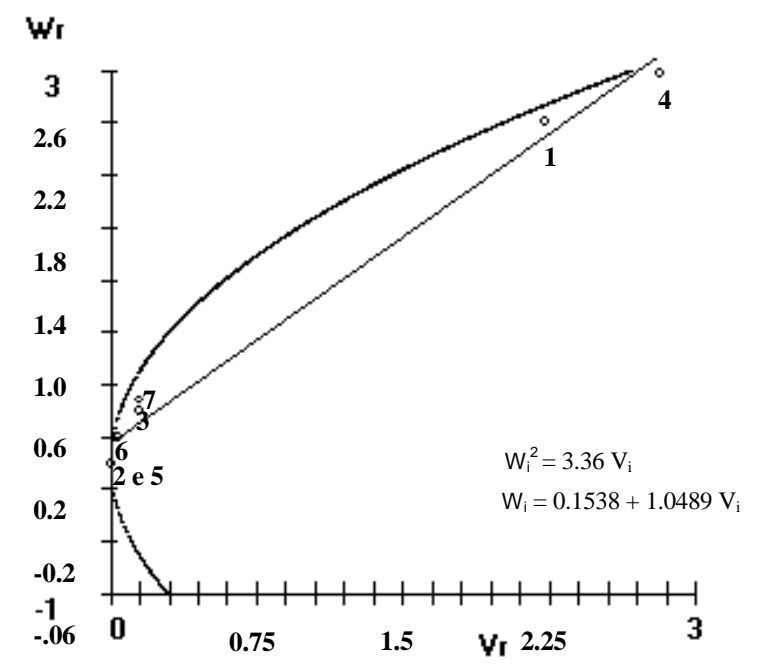

Figure $1-\mathrm{W}_{\mathrm{r}}$ and $\mathrm{V}_{\mathrm{r}}$ regression and limiting parabola, for resistance to Colletotrichum lindemuthianum, race 89. Parents: 1 (Michelite); 2 (Dark Red Kidney); 3 (Perry Marrow); 4 (Cornell 49-242); 5 (PI 207262); 6 (AB 136); 7 (G 2333). 
Table 2 - Estimates of the genetic components of the variance and the standard error for 89 and 31 races of Colletotrichum lindemuthianum, according to the Hayman methodology (1954)

\begin{tabular}{lcc}
\hline \multicolumn{1}{c}{$\begin{array}{c}\text { Component of variation } \\
\text { (nature of component) }\end{array}$} & \multicolumn{2}{c}{ Estimate \pm Standard error $^{1 /}$} \\
\cline { 2 - 3 }$\tilde{D}$ (Additive) & Race 89 & Race 31 \\
$\tilde{H}_{1}$ (Dominance) & $3.36 \pm 0.03^{*}$ & $2.86 \pm 0.02 *$ \\
$\tilde{H}_{2}$ (Dominance) & $2.60 \pm 0.02^{*}$ & $2.14 \pm 0.02 *$ \\
$\tilde{h}^{2}$ (Dominance) & $1.95 \pm 0.02^{*}$ & $2.21 \pm 0.02^{*}$ \\
$\tilde{F}$ (Additive-dominance) & $1.92 \pm 0.01^{*}$ & $-2.55 \pm-0.02^{*}$ \\
$\tilde{D}-\tilde{H}_{1}$ & $2.91 \pm 0.02^{*}$ & $0.52 \pm 0.00^{*}$ \\
$\tilde{E}$ (Enviromental) & $0.76 \pm 0.00^{*}$ & $0.25 \pm 0.025^{*}$
\end{tabular}

${ }^{1 /}$ Estimate of the component divided by its standard deviation that when greater than 1.96 is significant $(*)$ at $5 \%$ probability (Singh and Chaudhary, 1979)

${ }^{2 /} \tilde{D}=$ genetic component reference to additive genetic action; $\tilde{H}_{1}, \tilde{H}_{2}, \tilde{h}^{2}=$ genetic component for dominant genetic action; $\tilde{F}$ = genetic component, referring to the relative frequencies of dominant and recessive genes in the parent; $\tilde{D}_{-} \tilde{H}_{1}=$ component that expresses the difference among the additive and dominant effects and $\widetilde{E}=$ experimental errors.

These results confirmed that the $\mathrm{AB} 136$ and PI 207262 parents are recommended for breeding programs to obtain resistance to race 31 . Whereas, Michelite, Dark Red Kidney, Perry Marrow and Cornell 49-242 are not recommended, because they have concentration of recessive alleles, besides the fact that they are susceptible to race 31 . On the other hand, the $\sqrt{\tilde{H}_{1} / \tilde{D}}$ estimate indicates partial dominance. This shows that the use of backcross to introgression resistance to race 31 should be carried out with greater genetic representation and more accurate assessment of the ancestry.

The predominance of recessive homozygous forms was detected by the analysis of the ratio between dominant and recessive alleles in the parents of the group studied $\left(K_{D} / K_{R}=\right.$ 0.3410). This result explained the greater concentration of the parents on the opposite side to the intercept between the abscissa and the ordinate (Fig. 2). However, the value of 0.2286 for the $\tilde{H}_{2} / 4 \tilde{H}_{1}$ estimate (Table 3 ) indicated a tendency to symmetry in the frequencies among alleles that confer positive and negative effects for resistance.
The $\tilde{h}^{2} / \tilde{H}_{2}$ estimate revealed at least one gene that shows dominance for resistance to the race 31 pathogen in the studied parents. The $\tilde{D}$ component, estimator of additive variance and the estimative $\tilde{H}_{1}, \quad \tilde{H}_{2}$ and $\tilde{h}_{2}$ related to dominance (Table 2) showed the greater importance of the components associated to the additive effects than those related to the dominance effects that were also shown by the positive value of the $\widetilde{D}-\tilde{H}_{1}$.

The estimate of the number of genes that shows dominance was 1.0317 (Table 3). This result indicated that a small number of genes were involved. However, Cruz et al. (2004) stated that the number of genes that show little or no dominance is not considered by the Hayman's methodology (1954), so these estimates should be interpreted with care. 
Table 3 - Estimates of genetic parameters, obtained from the diallel analysis from reaction to race 89 and 31 of Colletotrichum lindemuthianum

\begin{tabular}{ccc}
\hline Genetic parameter $^{1 /}$ & Estimates of genetic component & \\
\hline$\sqrt{\tilde{H}_{1} / \tilde{D}}$ & Race 89 & Race 31 \\
$\tilde{H}_{2} / 4 \tilde{H}_{1}$ & 0.8791 & 0.9044 \\
$\tilde{h}^{2} / \tilde{H}_{2}$ & 0.1876 & 0.2286 \\
$\tilde{h}_{R}^{2}$ & 0.9854 & 1.0317 \\
$\tilde{h}_{A}^{2}$ & 0.5311 & 0.7812 \\
$K_{D} / K_{R}$ & 0.9923 & 0.9304 \\
$\mathrm{Y}_{\mathrm{D}}$ & 2.9333 & 0.3410 \\
$\mathrm{Y}_{\mathrm{R}}$ & 0.9307 & 1.1556 \\
\hline
\end{tabular}

1/ $\sqrt{\tilde{H}_{1} / \tilde{D}}=$ mean degree of dominance; $\tilde{H}_{2} / 4 \tilde{H}_{1}=$ distance of the alleles symmetry; $\tilde{h}^{2} / \tilde{H}_{2}=\mathrm{n}^{\circ}$ Genes with dominance; $\tilde{h}_{R}^{2}=$ genetic determination coefficient in the narrow sense; $\tilde{h}_{A}^{2}$ =genetic determination coefficient in the wide sense; $K_{D} / K_{R}=$ relation between dominant and recessive genes; $Y_{D}=$ predicted value of the genitor with maximum dominant allele concentration and $Y_{R}=$ predicted value for the parent with maximum recessive allele concentration.

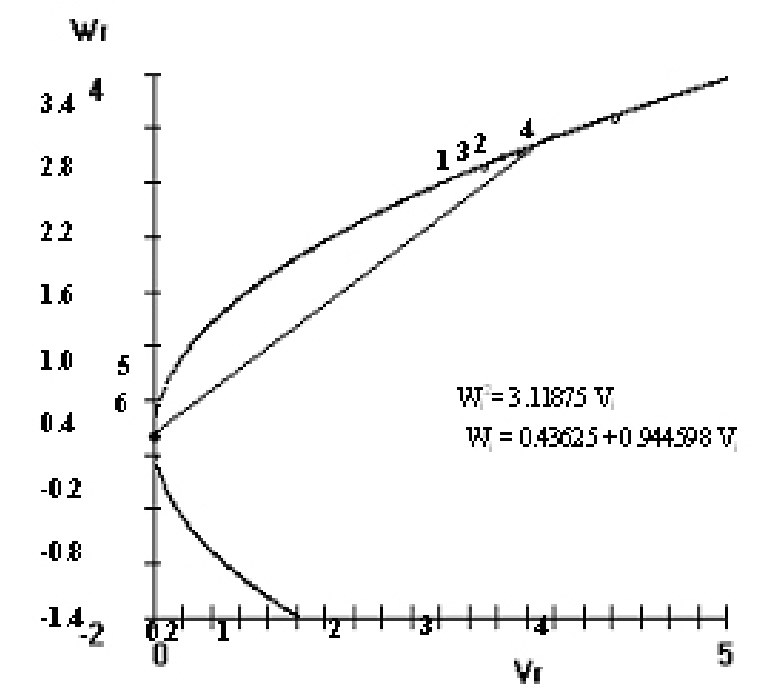

Figure $2-\mathrm{W}_{\mathrm{r}}$ and $\mathrm{V}_{\mathrm{r}}$ regression and limiting parabola, for resistance to Colletotrichum lindemuthianum race 31. Parents: 1, Michelite; 2, Dark Red Kidney; 3, Perry Marrow; 4, Cornell 49-242; 5, PI 207262; 6, AB 136. 


\section{Genetic determination coefficient estimate}

The values of the genotypic determination in the narrow sense 0.7812 and 0.5311 for the races 31 and 89 respectively showed the possibility of fast genetic gains by some type of selection since it quantifies the relative importance of the additive proportion of the genetic variation which could be transmitted to the next generation and would be fixed in the selection process. Therefore, the major importance of additive effects in the trait expression of resistance of the bean cultivars to $C$. lindemuthianum races 31 and 89 . The mean degree of dominance values showed the occurrence of complete dominance for races 31 and 89 . The greater dominant allele frequency present in the set of cultivars inoculated with race 89 was observed.

The narrow sense heritability for the races 31 , and 89 presented values of 0.7812 and 0.5311 respectively. Although, this fact demonstrated that is easier to obtain cultivars resistant to the race 31 than to the 89 race.

In the studies with such cultivars, GonçalvesVidigal (1994), Young and Kelly (1996) and Poletine et al. (2000), identified that the resistance to anthracnose was granted by dominant alleles. In Brazil, according to (Gonçalves-Vidigal et al., 1999; Poletine et al., 2000; Alzate Marín et al., 2003) the $\mathrm{Co}-4^{3}$ allele in PI 207262 is potentially source of resistance to anthracnose. Therefore, breeders should focus their attention on the $\mathrm{Co}-4^{2}$ allele as the best resistance source available at the Co-4 locus (Balardin and Kelly, 1998). The Co- $4^{2}$ gene was confirmed to be the only gene in the 3gene pyramid in G 2333 to afford resistance to the highly virulent race 2047 (Silverio et al., 2002). The results showed that dominance effects were higher than additive effects to resistance of the 89 race. The order of parents in relation to dominant genes concentration is: $\mathrm{G}$ 2333, $\mathrm{AB}$ 136, PI 207262, Cornell 49-242, Perry Marrow, Michigan Dark Red Kidney, and Michelite. The G 2333, AB 136 and PI 207262 cultivars should be recommended for obtaining cultivar resistance to anthracnose by backcross programs because it has the highest proportion of resistant dominant alleles.

\section{RESUMO}

Dentre as várias doenças que causam problemas no cultivo de feijão comum (Phaseolus vulgaris
L.), uma das mais importantes é a antracnose causada pelo fungo Colletotrichum lindemuthianum (Saac. et Magn.) Scrib., a qual pode resultar em severas perdas na produtividade de grãos. O controle genético, nas cultivares diferenciais Michelite, Michigan Dark Red Kidney, Perry Marrow, Cornell 49-242, PI 207262, AB 136 e G 2333 e seus 21 híbridos dialélicos, foi obtido usando a metodologia de Hayman (1954). Todas as populações $F_{1 \mathrm{~s}}$ foram avaliadas em relação à raça 89 , enquanto que os híbridos envolvendo a cultivar G 2333 não foram avaliados com a raça 31 . Os resultados demonstraram que os efeitos aditivos foram predominantes para a raça 31 , enquanto os efeitos gênicos não aditivos foram mais importantes na reação de incompatibilidade das cultivares a raça 89. Os resultados ainda evidenciaram um elevado coeficiente de determinação genética para a raça 31. Os cultivares G 2333, AB 136 e PI 207262 são os mais indicados para programas de melhoramento visando à obtenção de cultivares resistentes à antracnose por possuírem maior proporção de alelos dominantes para resistência às raças 31 e 89.

\section{REFERENCES}

Alzate-Marín, A. L. (1996), Resistência à antracnose do feijoeiro (Phaseolus vulgaris L.): diversidade genética de raças de Colletotrichum lindemuthianum, herança da resistência e identificação de marcadores moleculares. PhD Thesis, UFV, Viçosa, Minas Gerais, Brasil.

Alzate-Marín, A.L.; Morais Silva, M.A.; Oliveira, E.J.; Moreira, M.A. and Barros, E.G. (2003), Identification of the second anthracnose resistance gene present in the common bean cultivar PI 207.262. Annu. Rept. Bean Improv. Coop. ,46, 177-178.

Balardin, R. S., Jarosz, A. M., Kelly, J. D. (1997), Virulence and molecular diversity in Colletotrichum lindemuthianum from South, Central and North America. Phytopathology, 87, 1184-1191.

Balardin, R.S. and Kelly, J.D. (1998), Interaction among races of Colletotrichum lindemuthianum and diversity in Phaseolus vulgaris. J. Amer. Soc. Hort. Sci. 123, 1038-1047

Barelli, M. A. A.; Gonçalves-Vidigal, M. C.; Amaral Júnior, A. T.; Vidigal Filho, P. S. and Scapim, C. A.

(2000), Diallel analysis of the combining ability of common bean (Phaseolus vulgaris L.) cultivars. Brazilian Archives of Biology and Technology, 43, 409-414. 
Cárdenas, F.; Adams, M. W. and Andersen, A. (1964), The genetic system for reaction of field beans (Phaseolus vulgaris L.) to infection by three physiologic races of Colletotrichum lindemuthianum. Euphytica,13, 178-186.

Cruz, C. D. (2001), Programa Genes: aplicativo computacional em genética e estatística. Viçosa: UFV. pp. 394.

Cruz, C. D.; Regazzi, A. J. and Carneiro, P.C.S. (2004), Modelos biométricos aplicados ao melhoramento genético. Viçosa: UFV. pp. 480.

Del Peloso, M. J.; Cardoso, A. A.; Vieira, C.; Saraiva, L. S. and Zimmermann, M. J. de O. (1989), Genetic system for the reaction of Phaseolus vulgaris to the BA-2 (alpha) race of Colletotrichum lindemuthianum. Revista Brasileira de Genética, 12, 313-318.

Fukuda, W. M. G. (1982), Herança da resistência a três raças fisiológicas de Colletotrichum lindemuthianum (Sacc. et Magn.) Scrib. em feijoeiro comum (Phaseolus vulgaris L.). Master's Thesis, UFV, Viçosa, Minas Gerais, Brasil.

Garrido-Ramirez, E. R. and Romero-Cova, S. (1989), Identification de razas fisiológicas de Colletotrichum lindemuthianum en Mexico y busqueda de resistencia genetica a este hongo. Agrociencia, 77, 139-156.

Gonçalves-Vidigal, M. C. (1994), Herança da resistência às raças alfa, delta e capa de Colletotrichum lindemuthianum (Sacc. et Magn.) Scrib. no feijoeiro (Phaseolus vulgaris L.). $\mathrm{PhD}$ Thesis, UFV, Viçosa, Minas gerais, Brasil.

Gonçalves-Vidigal, M.C.; Sakiyama, N.S.; Oliveira, V.R.; Amaral Junior, A.T.; Vidigal Filho, P.S. and Silvério, L. (1999), Experimental evidence of a single dominant gene (Co-6) controlling AB 136 resistance to races 31 and 69 of Colletotrichum lindemuthianum. Annu. Rept. Bean Improv. Coop. ,42, 11-12.

Hayman, B. I. (1954), The theory and analysis of diallel crosses. Genetics, 39, 789-809.

Mathur, R.S.; Barnett, H.L. and Lilly, V.G. (1950), Sporulation of Colletotrichum lindemuthianum in culture. Phytopathology, 40,104-114.

Melloto, M. and Kelly, J. D. (2000), An allelic series at the Co-1 locus conditioning resistance to anthracnose in common bean of Andean origin. Euphytica, 116, 143-149.

Menezes, J. R. and Dianese, J. C. (1988), Race characterization of Brazilian isolates of Colletotrichum lindemuthianum and detection of resistance to anthracnose in Phaseolus vulgaris. Phytopathology, 78, 650-655.

Muhalet, C. S.; Adams, M. W.; Saettler, A. W. and Ghaderi, A. (1981), Genetic system for the reaction of field beans to beta, gamma, and delta races of Colletotrichum lindemuthianum. Journal of American Society for Horticultural Science, 106, 601-604.
Pastor-Corrales, M. A. (1991), Estandartización de variedades diferenciales y designación de razas de Colletotrichum lindemuthianum. (Abstr.). Phytopathology, 81, 694.

Pastor-Corrales, M. A., Otoya, M. M., Molina, A., and Singh, S. P. (1995), Resistance to Colletotrichum lindemuthianum isolates from Middle America and Andean South America in different common bean races. Plant Disease, 79, 63-67.

Poletine, J. P. (1997), Herança da resistência do feijoeiro (Phaseolus vulgaris L.) às raças 69 (epsilon) e 453 (zeta) de Colletotrichum lindemuthianum (Saac. et Magn.) Scrib.. Master's Thesis, UEM, Maringá, PR.

Poletine, J.P.; Gonçalves-Vidigal, M.C.; Vidigal Filho, P.S.; Scapim, C.A.; Silverio, L. and Thomazella, C. (2000), Inheritance of resistance to races 69 and 453 of Colletotrichum lindemuthianum in the common bean. Brazilian Archives of Biology and Technology, 43, 479-485.

Pompeu, A. S.; Ito, M. F. and Dudienas, C. (1992), Linhagens de feijoeiro resistentes ao fungo da antracnose (Colletotrichum lindemuthianum) obtidas pelo uso dos genes Mex.2 e Mex.3. Summa Phytopathologica, 18, 220-226.

Rava, C. A.; Purchio, A. F. and Sartorato, A. (1994), Caracterização de patótipos de Colletotrichum lindemuthianum que ocorrem em algumas regiões produtoras de feijoeiro comum. Fitopatologia Brasileira, 19, 167-172.

Silva, M. P.; Amaral Júnior, A.T.; Rodrigues, R.; Pereira, M. G. and Viana, A. P. (2004), Genetic control on morphoagronomic traits in snap bean. Brazilian Archives of Biology and Technology, 47, 855-862.

Silverio, L.; Gonçalves-Vidigal, M.C.; Vidigal Filho, P.S.; Barelli, M.A.A.; Thomazella, C. and Nunes, W.M.C. (2002), Genetic resistance to Colletotrichum lindemuthianum race 2047 in G 2333. Annu. Rept. Bean Improv. Coop., 45, 74-75.

Thomazella, C.; Gonçalves-Vidigal, M.C.; Vida, J.B.; Vidigal Filho, P.S. and Rimoldi, F. (2000), Identification of Colletotrichum lindemuthianum races in Phaseolus vulgaris L. Annu. Rept. Bean Improv. Coop., 43, 82-83.

Vieira, C.; Paula Júnior, T. J. de and Borém, A. (1998), Feijão: Aspectos gerais e cultura no Estado de Minas. Viçosa: Imprensa Universitária. pp 596.

Yerkes Júnior, W. D. and Ortiz, M.T. (1956), New races of Colletotrichum lindemuthianum in México. Phytopathology, 46, 564-567.

Young, R. A. and Kelly, J. (1997), RAPD markers linked to three major anthracnose resistance genes in common bean. Crop Science, 37, 940-94. 